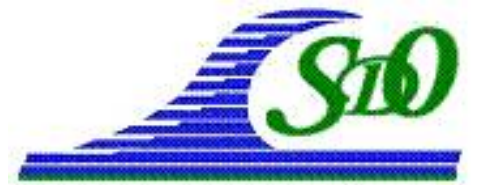

XI ${ }^{\text {ìmes }}$ Journées Nationales Génie Côtier - Génie Civil

Les Sables d'Olonne, 22-25 juin 2010

DOI:10.5150/jngcgc.2010.006-B @ Editions Paralia CFL

disponible en ligne - http://www.paralia.fr - available online

\title{
Numerical study of boundary shear stress distribution in rectangular open channel flow
}

\author{
Hossein BONAKDARI ${ }^{1,2}$, Mohtaram TOOSHMALANI ${ }^{1,2}$, \\ Daniel LEVACHER ${ }^{3}$, Gislain LIPEME KOUYI ${ }^{4}$
}

1. Department of Civil Engineering, University of Razi, Kermanshah, Iran. bonakdari@yahoo.com

2. Water and Wastewater Research Center, University of Razi, Kermanshah, Iran.

3. Caen University, UMR 6143 CNRS - M2C, 14032 Caen, France.

4. Laboratory of Civil \& Environmental Engineering, LGCIE, INSA Lyon, France.

\begin{abstract}
:
Boundary shear stresses have been calculated for rectangular open channel with different roughnesses using computational fluid dynamics (CFD). CFD simulations were carried out for rectangular free surface flow in order to check the software package for its ability to reproduce experimental results not only for the prediction of the velocity field but also for the shear stress distribution. A research program, therefore, is in progress to study how flows behave in such channels and the 3D numerical simulations can be used systematically to investigate some parameters viz. velocity field, shear stress whole of cross section. The influence of the bottom and side walls roughness on velocity field and shear stress was studied for rectangular turbulent open channel. With the help of the detailed shear stress distribution, sediment transport can be calculated more accurately than using the global shear stress, as is traditionally done.
\end{abstract}

\section{Keywords:}

Shear stress - Numerical model - Computational fluid dynamic - Sediment transport Open channel

\section{Communication non présentée}


Thème 1 - Hydrodynamique côtière 
XI ${ }^{\text {èmes }}$ Journées Nationales Génie Côtier - Génie Civil

Les Sables d'Olonne, 22-25 juin 2010 
Thème 1 - Hydrodynamique côtière 
XI ${ }^{\text {èmes }}$ Journées Nationales Génie Côtier - Génie Civil

Les Sables d'Olonne, 22-25 juin 2010 
Thème 1 - Hydrodynamique côtière 
XI ${ }^{\text {èmes }}$ Journées Nationales Génie Côtier - Génie Civil

Les Sables d'Olonne, 22-25 juin 2010 
Thème 1 - Hydrodynamique côtière 